\title{
PENGARUH PEMBERIAN TEPUNG SORGUM (Sorghum bicolor L. Moench) TERHADAP TEKANAN DARAH SISTOLIK TIKUS WISTAR (Rattus norvegicus) DIABETES
}

\author{
Rochanisa Sita Arifani, Nurmasari Widyastuti", Choirun Nissa \\ Departemen Ilmu Gizi, Fakultas Kedokteran, Universitas Diponegoro \\ Jl. Prof. Sudarto SH, Tembalang, Semarang, Jawa Tengah 50275, Indonesia \\ "Penulis Penanggungjawab. E-mail: widyastutinurmasari@gmail.com
}

\begin{abstract}
Background: Diabetes mellitus (DM) is a collection of symptoms that arise in a person caused by an increase in blood glucose levels due to a progressive decrease in insulin secretion due to insulin resistance. Insulin resistance results in an increase in body fat which can interfere with the work of the nervous system, including signals that regulate blood pressure thereby causing an increase in systolic blood pressure. Consuming high-fiber cereals and antioxidants such as sorghum can reduce systolic blood pressure. The aim of the study is to determine the effect of sorghum flour on systolic blood pressure of diabetic wistar rats.

Methods: Research with true experimental design pre and post test with randomized control group design. Samples used were 18 male wistar rats, divided into 3 groups randomly namely positive control $(K+)$, negative $(K-)$, and sorghum flour treatment $(P) . K+$ and $P$ injected at STZ $45 \mathrm{mg} / \mathrm{kgBB}$ and $N A 110 \mathrm{mg} / \mathrm{kgBB}$. Group $K$ - and $\mathrm{K}+$ were given standard feed of $20 \mathrm{~g} /$ day, while $P$ was given food consisting of sorghum flour $5 \mathrm{~g} /$ day and standard feed of 15 $g /$ day for 28 days. Three days after injection, the 14th day of the intervention, and after the intervention the rat was examined for systolic blood pressure using a direct measurement method in the tail of the wistar rats non-invasively using a spyghmomanometer. Intervention of sorghum flour in group $P$ was given for 28 days. Data analysis used paired $t$-test, one way anova, and kruskal wallis.

Results: There was a significant difference in rat systolic blood pressure before the intervention $(p=0.003)$ and after the intervention $(p=0.001)$. The $K$ - and $K+$ groups experienced an increase in systolic blood pressure and in the $P$ group there was a decrease in systolic blood pressure. Systolic blood pressure reduction in the treatment group was $89.3 \mathrm{mmHg}(43.9 \%)$.

Conclusion: Sorghum flour can significantly reduce systolic blood pressure of diabetic wistar rats.
\end{abstract}

Keywords: Sorghum flour; diabetes; systolic blood pressure

\begin{abstract}
ABSTRAK
Latar Belakang: Diabetes Melitus (DM) adalah suatu kumpulan gejala yang timbul pada seseorang yang disebabkan karena adanya peningkatan kadar glukosa darah akibat penurunan sekresi insulin yang progresif dilatarbelakangi oleh resistensi insulin. Resistensi insulin mengakibatkan peningkatan lemak tubuh yang dapat mengganggu kerja sistem saraf, termasuk sinyal yang mengatur tekanan darah sehingga menyebabkan peningkatan tekanan darah sistolik. Mengkonsumsi serealia tinggi serat dan antioksin seperti sorgum dapat menurunkan tekanan darah sistolik. Tujuan penelitian ini adalah mengetahui pengaruh pemberian tepung sorgum terhadap tekanan darah sistolik tikus wistar diabetes.

Metode: Penelitian dengan desain true experimental pre and post test with randomized control group design. Sampel yang digunakan 18 ekor tikus wistar jantan, dibagi dalam 3 kelompok secara acak yaitu kontrol positif $(K+)$, negatif $(K$-), dan perlakuan tepung sorgum $(P)$. $K+$ dan $P$ di injeksi $S T Z 45 \mathrm{mg} / \mathrm{kgBB}$ dan NA $110 \mathrm{mg} / \mathrm{kgBB}$. Kelompok $\mathrm{K}-$ dan $K+$ diberi pakan standar sebanyak $20 \mathrm{~g} / \mathrm{hari}$, sedangkan $P$ diberi pakan yang terdiri dari tepung sorgum $5 \mathrm{~g} / \mathrm{hari}$ dan pakan standar sebanyak $15 \mathrm{~g}$ /hari selama 28 hari. Tiga hari setelah injeksi, hari ke-14 intervensi, dan paska intervensi tikus diperiksa tekanan darah sistolik menggunakan metode pengukuran langsung di ekor tikus secara non invasif menggunakan spyghmomanometer. Intervensi pemberian tepung sorgum pada kelompok P diberikan selama 28 hari. Analisis data menggunakan uji paired $t$-test, one way anova, dan kruskal wallis.

Hasil: Terdapat perbedaan signifikan tekanan darah sistolik tikus sebelum intervensi $(p=0,003)$ dan setelah intervensi $(p=0,001)$. Kelompok $K$ - dan $K+$ mengalami peningkatan tekanan darah sistolik dan pada kelompok $P$ terjadi penurunan tekanan darah sistolik. Penurunan tekanan darah sistolik pada kelompok perlakuan sebesar $89,3 \mathrm{mmHg}$ $(43,9 \%)$.
\end{abstract}

Simpulan: Tepung sorgum dapat menurunkan tekanan darah sistolik tikus wistar diabetes secara signifikan.

Kata kunci : Tepung sorgum; diabetes; tekanan darah sistolik 


\section{PENDAHULUAN}

Badan kesehatan dunia World Heath Organization (WHO), tahun 2013 melaporkan bahwa lebih dari $80 \%$ kematian akibat Diabetes Mellitus (DM) terjadi di negara berpendapatan rendah-menengah. Hal ini juga ditunjukkan pada wilayah Asia bahwa yang mengalami diabetes 5,5\% menjadi 13,2\% dalam 3 tahun. Indonesia, menurut WHO tahun 2012, merupakan negara ke dua terbesar setelah India yang mempunyai penderita DM terbanyak yaitu 8.426.000 orang di tingkat Asia Tenggara, dan diperkirakan meningkat menjadi 21.257.000 pada tahun 2030. ${ }^{1}$

Diabetes Melitus (DM) adalah suatu kumpulan gejala yang timbul pada seseorang yang disebabkan oleh karena adanya peningkatan kadar glukosa darah akibat penurunan sekresi insulin yang progresif dilatarbelakangi oleh resistensi insulin. ${ }^{2}$ Hormon insulin berfungsi untuk mengatur keseimbangan kadar gula dalam darah sebagai akibat dari gangguan produksi hormon insulin, akan terjadi kenaikan kadar gula darah di atas batas normal. $^{2}$ Diabetes erat hubungannya dengan hipertensi. Diabetes dan hipertensi adalah kondisi yang umum terjadi di masyarakat dan merupakan faktor risiko penting penyakit kardiovaskular. Hipertensi lebih sering terjadi pada populasi diabetes dibandingkan populasi non-diabetes. ${ }^{3}$

Hipertensi dapat terjadi bersamaan (komorbid) dengan diabetes atau merupakan akibat proses patologis diabetes. Patogenesis hipertensi pada diabetes merupakan proses yang kompleks dan belum sepenuhnya dapat dijelaskan. ${ }^{2}$ Hipertensi merupakan faktor risiko utama untuk terjadinya DM. Hubungannya dengan DM adalah hipertensi dapat membuat sel tidak sensitif terhadap insulin (resisten insulin). ${ }^{3}$ Insulin berperan meningkatkan ambilan glukosa di banyak sel dan dengan cara ini juga mengatur metabolisme karbohidrat, sehingga jika terjadi resistensi insulin oleh sel, maka kadar gula di dalam darah juga dapat mengalami gangguan. ${ }^{4}$ Disfungsi otonom, aktivasi sistem ReninAngiotensin Aldosterone (RAAS), resistensi insulin, aktivasi saraf simpatis, disfungsi endotel, dan kekakuan pembuluh darah arteri merupakan sebagian faktor yang diketahui berkontribusi pada terjadinya hipertensi pada diabetes. ${ }^{5}$ Hasil penelitian terhadap aktivitas antioksidan pada sorgum menunjukkan bahwa aktivitas antioksidan yang terdapat di dalam sorgum sebesar 89,32\%. ${ }^{6}$ Antioksidan yang terdapat dalam sorgum salah satunya adalah antosianin. Antosianin berperan mengurangi resistensi insulin dan meningkatkan sensitivitas insulin sehingga mampu menghambat hormone sensitive lipase (HSL) agar tidak terjadi lipolisis dan peningkatan asam lemak bebas sehingga dapat menurunkan tekanan darah. ${ }^{7}$

Hipertensi juga merupakan faktor risiko utama penyakit-penyakit kardiovaskular yang merupakan penyebab kematian tertinggi di Indonesia pada tahun $2010 .{ }^{8}$ Bahkan orang yang menderita DM terutama tipe 2 memiliki resiko 2 sampai 4 kali lebih rentan mengalami kematian karena kelainan kardiovaskular daripada orang yang tidak menderita DM dan hipertensi terjadi 2 kali lebih rentan pada pasien dengan DM dibandingkan non DM pada kelompok usia yang sama. ${ }^{9}$

Hipertensi terjadi ketika tekanan darah sistolik dan diastolik lebih tinggi dari batas normal tekanan darah. Tekanan darah sistolik merupakan tekanan darah yang berkontraksi memompa darah dari ventrikel kiri jantung oleh pembuluh darah aorta ke seluruh tubuh, sedangkan tekanan darah diastolik adalah tekanan darah yang berelaksasi memompa darah dari atrium ke ventrikel. Tekanan darah diastolik tidak akan lebih tinggi dari tekanan darah sistolik. Tekanan darah sistolik yang tinggi dapat menunjukkan terjadinya hipertensi pada seseorang yang kemudian di ikuti kenaikan oleh tekanan darah diastolik. ${ }^{9}$

Diet pangan tinggi serat yaitu whole grains sudah dikembangkan untuk masalah hipertensi dan diabetes mellitus. Diet ini berfungsi menetralkan dan mempercepat degradasi senyawa radikal bebas untuk mencegah kerusakan komponen makromolekul sel. ${ }^{10}$ Salah satu jenis pangan yang dapat digunakan adalah sorgum. Sorgum merupakan tanaman jenis serealia yang sekeluarga dengan padi, jagung, dan gandum. Tanaman jenis serealia menyumbang energi yang lebih tinggi yaitu sebesar 50\% daripada kelompok lain seperti umbi-umbian $6 \%$, pangan hewani $12 \%$, minyak dan lemak $10 \%$, buah dan biji berminyak $3 \%$, kacang-kacangan 5\%, gula 5\%, sayur dan buah $6 \%$, lain-lain (bumbu) 3\%.11 Oleh karena serealia memberikan energi yang cukup besar dibanding dengan bahan jenis lain, maka hal tersebut mempengaruhi persentase kuantitas serealia yang dimakan. Apabila seseorang ingin mencukupi energi dengan cepat, maka porsi makan serealia juga besar. ${ }^{12}$

Sorgum merupakan salah satu jenis tanaman serealia yang ada di Indonesia dan mempunyai kandungan zat gizi yang cukup tinggi, yaitu mengandung protein sebanyak $8 \%$ sampai $12 \%$ setara dengan terigu atau lebih tinggi dibandingkan dengan beras yaitu $6 \%$ sampai $10 \%$ dan kandungan lemaknya sebanyak $2 \%$ sampai $6 \%$ lebih tinggi dibandingkan dengan beras yaitu 0,5 sampai $1,5 \%$ dan sorgum memiliki kandungan lemak 3,65\%, serat kasar $7,6 \%$ sampai $9,2 \%$, abu $2,24 \%$, dan pati $78,74 \% .^{10,11}$ 
Serat sorgum tersebut lebih tinggi jika dibandingkan dengan serat beras yaitu 1 gram. ${ }^{11}$ Serat pangan berfungsi memperlambat pencernaan dalam usus, memberikan rasa kenyang lebih lama, serta memperlambat kemunculan glukosa darah. ${ }^{12}$ Serat pangan berfungsi mengikat asam empedu sehingga menurunkan kadar kolesterol darah. ${ }^{12}$ Serat juga dapat menurunkan tekanan darah. Serat larut air mencegah penyerapan asam empedu, kolesterol, dan lemak sehingga darah yang pekat akan menjadi lebih encer dan tekanan perifernya akan menjadi berkurang. ${ }^{11}$ Berdasarkan uraian tersebut, perlu dilakukan penelitian mengenai pengaruh pemberian tepung sorgum terhadap tekanan darah sistolik tikus wistar (Rattus norvegicus) diabetes. Tujuan dari penelitian ini yaitu untuk mengetahui pengaruh pemberian tepung sorgum terhadap tekanan darah sistolik tikus wistar diabetes.

\section{METODE}

Penelitian ini memiliki jenis true experimental dengan desain pre and post randomized control group. Pengambilan data dilakukan di Laboraturium Pusat Studi Pangan dan Gizi Universitas Gadjah Mada (Lab. PSPG UGM). Tikus didapatkan dari Unit Pengembangan Hewan Coba Universitas Gadjah Mada (UPHP UGM). Penelitian dilakukan pada bulan Maret-Mei 2019. Subjek yang digunakan pada penelitian ini adalah tikus jantan galur wistar (Rattus norvegicus), Pemilihan galur wistar dikarenakan galur tersebut memiliki kemampuan metabolik yang relatif cepat, sehingga lebih sensitif bila digunakan dalam penelitian yang berhubungan dengan metabolik tubuh. Tikus yang dipilih berjenis kelamin jantan karena dapat memberikan hasil penelitian yang lebih stabil karena tidak dipengaruhi oleh siklus estrus, hormon esterogen, dan kehamilan. Kriteria inklusi tikus berumur 8-12 minggu dengan berat badan awal 180-200 gram, tikus dalam kondisi sehat (tidak cacat dan bergerak aktif).

Besar sampel minimal dihitung menurut World Health Organization (WHO) yaitu setiap kelompok perlakuan sebanyak 5 ekor tikus, untuk mengantisipasi adanya drop-out maka setiap kelompok ditambah 1 ekor tikus, sehingga pada penelitian ini tikus yang digunakan sejumlah 18 ekor yang dibagi menjadi 3 kelompok yaitu:

K- : Kelompok kontrol negatif yaitu tikus sehat yang diberikan pakan standar

$\mathrm{K}+$ : Kelompok kontrol positif yaitu tikus DM yang diberikan pakan standar

$\mathrm{P} \quad$ : Kelompok perlakuan (tikus DM) dengan perlakuan tepung sorgum

Tikus dipelihara dalam ruangan berventilasi dengan suhu ruangan berkisar antara $28-32^{\circ} \mathrm{C}$ dan siklus pencahayaan 12 jam (siklus terang 06.0018.00). Setelah masa aklimatisasi, tikus kelompok kontrol positif dan perlakuan di injeksi STZ 45 $\mathrm{mg} / \mathrm{kgBB}$ dan NA $110 \mathrm{mg} / \mathrm{kgBB}$ secara intraperitoneal. Tiga hari setelah injeksi tikus diperiksa tekanan darahnya menggunakan metode pengukuran langsung di ekor tikus secara non invasif menggunakan spyghmomanometer, arteri yang digunakan untuk pengukuran tekanan darah adalah arteri ekor tikus dan hanya tekanan darah sistolik saja yang dapat terbaca oleh alat tersebut. Kemudian tikus dipuasakan selama 8-10 jam kemudian diambil darahnya sebanyak $3 \mathrm{ml}$ melalui sinus retro-orbital. Darah yang sudah diambil dianalisis kadar glukosa darah puasa (GDP) sebelum diberikan intervensi. Selama masa intervensi, tikus kelompok kontrol positif dan negatif diberikan pakan standar comfeed AD II sebanyak 20 gram/tikus/hari.

Pakan standar comfeed AD II mengandung 50 gram karbohidrat, 6 gram serat kasar, 7 gram lemak dan 15 gram protein dalam 100 gram pakan standar. Kandungan zat gizi dalam 100 gram tepung sorgum yaitu 73,6 gram karbohidrat, serat total 8,83 gram, lemak 4,14 gram dan protein 8,91 gram. Tikus kelompok perlakuan diberikan pakan intervensi sebanyak 20 gram/tikus/hari. Pakan intervensi yang diberikan berupa tepung sorgum yang telah di homogenisasi dengan pakan standar comfeed AD II (tepung sorgum $25 \%$ : pakan standar $75 \%$ ). Dosis yang digunakan diperoleh dari kadar serat tepung sorgum dalam 100 gram yaitu 8,83 gram dikalikan dengan kebutuhan serat untuk pasien DM yaitu 20 gram, kemudian dikonversikan ke dosis tikus dengan angka konversi tikus yaitu 0,018 dan diperoleh 4,1 gram serat tepung sorgum.

Sorgum didapatkan dalam bentuk biji dari Pracimantoro, Wonogiri. Biji sorgum yang digunakan adalah biji yang tidak disosoh, tidak terdapat kutu, dan tidak terdapat kapang. Biji sorgum tersebut diolah menjadi tepung sorgum dengan cara menggiling biji menggunakan grinder kemudian mengayaknya dengan ayakan berukuran 70 mesh. Tepung sorgum dicampurkan dengan pakan standar dengan jumlah tepung sorgum sebanyak $5 \mathrm{~g}$ dan pakan standar sebanyak $15 \mathrm{~g}$. Campuran tersebut dicetak dalam bentuk pellet menggunakan ekstruder lalu dikeringkan pada suhu $\pm 40^{\circ} \mathrm{C}$ menggunakan cabin dryer selama 8 jam. Pakan campuran ini dibuat di Lab. PSPG UGM sebanyak satu kali pada awal penelitian.

Data hasil pemeriksaan tekanan darah diuji normalitas dengan uji Shapiro-Wilk. Perbedaan tekanan darah sebelum dan setelah pemberian tepung sorgum pada kelompok $\mathrm{K}-, \mathrm{K}+$, dan $\mathrm{P}$ diuji menggunakan Paired T-Test pada data yang 
berdistribusi normal dan menggunakan Wilcoxon pada data yang berdistribusi tidak normal. Perbedaan pengaruh antar kelompok dianalisis dengan uji statistik parametrik Anova pada data yang berdistribusi normal dan dilanjutkan dengan uji Post Hoc Duncan. Data yang berdistribusi tidak normal diuji statistik non-parametrik Kruskal Wallis dan dilanjutkan dengan Mann-Whitney Test untuk melihat perbedaan pengaruh antar kelompok. Penelitian ini telah memperoleh persetujuan dari Komisi Etik Penelitian Kesehatan (KEPK) Fakultas Kedokteran Universitas Diponegoro No.18/EC/H/FK-UNDIP/III/2019.

\section{HASIL \\ Karakteristik Subjek Penelitian Setelah Injeksi Streptozotocin (STZ) dan Nicotinamide (NA)}

Tikus wistar jantan sebanyak 18 ekor dikandangkan secara individu dan tidak ada drop out selama penelitian berlangsung. Tabel 1 menunjukkan gambaran karakteristik subjek setelah tiga hari injeksi STZ-NA dan dilakukan pemeriksaan kadar glukosa darah puasa (GDP). Berdasarkan tabel 1, kelompok kontrol negatif (K-) memiliki rata-rata GDP pada rentang normal, sedangkan pada kelompok kontrol positif $(\mathrm{K}+)$ dan kelompok perlakuan $(\mathrm{P})$ telah memenuhi kriteria tikus diabetes (GDP > $250 \mathrm{mg} / \mathrm{dl}$ ). Berdasarkan hasil uji Post Hoc Duncan menunjukkan terdapat perbedaan GDP yang signifikan antara kelompok kontrol negatif (K-) dan kelompok kontrol positif $(\mathrm{K}+)$, namun tidak terdapat perbedaan pada kelompok $\mathrm{K}(+)$ dan kelompok perlakuan (P). Tidak terdapat perbedaan yang signifikan pada rerata berat badan tikus antar kelompok $(p>0,05)$.

Tabel 1. Karakteristik Subjek Setelah Injeksi STZ-NA

\begin{tabular}{|c|c|c|c|c|c|}
\hline \multirow[b]{2}{*}{ Variabel } & \multirow[b]{2}{*}{$\mathbf{n}$} & \multicolumn{4}{|c|}{ Rerata \pm SD } \\
\hline & & $\begin{array}{c}\text { Kontrol negatif } \\
(\mathrm{K}-)\end{array}$ & $\begin{array}{c}\text { Kontrol positif } \\
(\mathrm{K}+)\end{array}$ & $\begin{array}{c}\text { Perlakuan } \\
\text { (P) }\end{array}$ & $p$ \\
\hline Gula Darah Puasa & 6 & $67,8 \pm 1,79^{a}$ & $267 \pm 2,71^{b^{*}}$ & $267 \pm 3,34^{b^{*}}$ & $0,001^{1^{* *}}$ \\
\hline BB awal hari 1 (gram) & 6 & $187,5 \pm 3,93$ & $186,0 \pm 4,60$ & $187,3 \pm 4,67$ & $0,815^{1}$ \\
\hline BB paska induksi hari 12 (gram) & 6 & $194,0 \pm 3,63$ & $192,5 \pm 4,50$ & $194,0 \pm 4,81$ & $0,791^{1}$ \\
\hline BB paska intervensi hari 41 (gram) & 6 & $218,1 \pm 3,35^{\mathrm{c}}$ & $177,1 \pm 4,96^{\mathrm{a}}$ & $205,9 \pm 2,85^{b}$ & $0,001^{1 * *}$ \\
\hline Pakan (gram) & 6 & $17,0 \pm 0,24^{\mathrm{a}}$ & $18,6 \pm 0,14^{\mathrm{b}}$ & $17,0 \pm 0,23^{\mathrm{a}}$ & $0,001^{1 * *}$ \\
\hline
\end{tabular}

Terdapat peningkatan rerata berat badan yang signifikan pada kelompok kontrol negatif (K-) dan kelompok perlakuan $(\mathrm{P})$ pada saat aklimatisasi, pengkondisian DM, dan intervensi. Pada kelompok kontrol positif $(\mathrm{K}+)$ terdapat peningkatan rerata berat badan yang signifikan selama aklimatisasi hingga pengkondisian DM, tetapi terdapat penurunan yang signifikan selama pengkondisian DM hingga intervensi. Tidak terdapat perbedaan berat badan yang signifikan antar kelompok pada semua fase kecuali fase intervensi $(p<0,05)$

Terdapat perbedaan yang signifikan pada rerata konsumsi pakan tikus antar kelompok kontrol negatif (K-), kelompok kontrol positif $(\mathrm{K}+)$, dan kelompok perlakuan (P) selama masa intervensi $(p<0,05)$. Uji Post Hoc Duncan terhadap rerata konsumsi pakan tikus selama intervensi menunjukkan bahwa tidak terdapat perbedaan rerata konsumsi pakan pada kelompok kontrol negatif (K-) dan kelompok perlakuan (P), tetapi terdapat perbedaan dengan kelompok kontrol positif $(\mathrm{K}+)$

Tekanan Darah Tikus

Terdapat peningkatan rerata tekanan darah yang signifikan pada kelompok kontrol negatif (K-) dan kelompok kontrol positif $(\mathrm{K}+)$ setelah pemberian perlakuan, serta pada kelompok perlakuan $(\mathrm{P})$ terjadi penurunan yang signifikan pada rerata tekanan darah tikus setelah pemberian perlakuan. Uji Mann Whitney terhadap rerata tekanan darah tikus setelah injeksi STZ-NA menunjukkan bahwa tidak terdapat perbedaan rerata tekanan darah pada kelompok kontrol negatif $(\mathrm{K}+)$ dan kelompok perlakuan $(\mathrm{P})$, tetapi terdapat perbedaan dengan kelompok kontrol positif (K-). Selain itu, terdapat perbedaan tekanan darah tikus yang signifikan antar kelompok saat sebelum intervensi dan setelah intervensi $(p<0,05)$.

Terdapat perbedaan signifikan delta perubahan tekanan darah sebelum dan setelah intervensi pada masing-masing kelompok $(p<0,05)$. Selain itu juga terdapat perbedaan signifikan antar kelompok delta perubahan tekanan darah $(p<0,05)$. Perubahan tekanan darah yang terbesar yaitu pada kelompok $\mathrm{P}$ dengan penurunan sebesar $43,9 \%$. Pada kelompok K- dan $\mathrm{K}+$ terjadi peningkatan tekanan darah sebesar $3,4 \%$ dan $4,0 \%$. 
Tabel 2. Tekanan Darah Tikus Sebelum dan Sesudah Pemberian Intervensi

\begin{tabular}{|c|c|c|c|c|c|}
\hline \multirow[b]{2}{*}{ Variabel } & \multirow[b]{2}{*}{$\mathbf{n}$} & \multicolumn{4}{|c|}{ Rerata \pm SD } \\
\hline & & $\begin{array}{c}\text { Kontrol } \\
\text { negatif (K-) }\end{array}$ & $\begin{array}{c}\text { Kontrol } \\
\text { positif }(\mathbf{K}+)\end{array}$ & $\begin{array}{c}\text { Perlakuan } \\
\text { (P) }\end{array}$ & $p$ \\
\hline Tekanan Darah Paska Induksi hari $12(\mathrm{mmHg})$ & 6 & $90,0 \pm 4,47^{d}$ & $201,5 \pm 4,37^{\mathrm{e}}$ & $203,0 \pm 9,25^{\mathrm{e}}$ & $0,003^{* 2}$ \\
\hline Tekanan Darah Tengah Intervensi hari $26(\mathrm{mmHg})$ & 6 & $92,5 \pm 2,07^{\mathrm{d}}$ & $207,3 \pm 5,53 \mathrm{e}$ & $164,3 \pm 7,73^{\mathrm{f}}$ & $0,001^{* 2}$ \\
\hline Tekanan Darah Paska Intervensi hari 41 (mmHg) & 6 & $93,1 \pm 3,12^{\mathrm{a}}$ & $209,6 \pm 3,26^{b}$ & $113,6 \pm 2,16^{\mathrm{c}}$ & $0,001^{* 1}$ \\
\hline Perubahan Tekanan Darah $(\mathrm{mmHg})$ & 6 & $3,1 \pm 3,31^{\mathrm{d}}$ & $8,1 \pm 5,91^{\mathrm{e}}$ & $-89,3 \pm 9,1^{f}$ & $0,002^{* 2}$ \\
\hline Persen Perubahan Tekanan Darah (\%) & 6 & 3,4 & 4,0 & 43,9 & \\
\hline
\end{tabular}

Tekanan Darah Sistolik Kelompok Kontrol Negatif, Kelompok Kontrol Positif, dan Kelompok Perlakuan

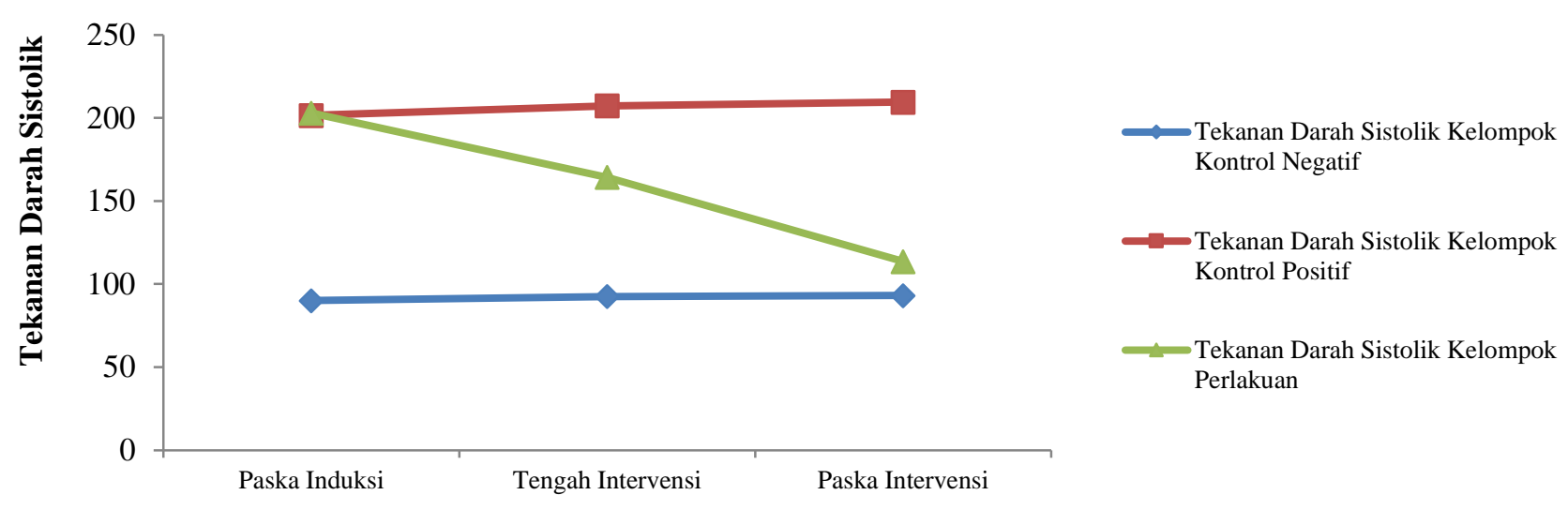

Gambar 1. Perubahan Tekanan Darah Sistolik Kelompok Kontrol Negatif, Kelompok Kontrol Positif, dan Kelompok Perlakuan

\section{PEMBAHASAN}

Pengkondisian DM dilakukan pada tikus wistar kelompok $\mathrm{K}+$ dan $\mathrm{P}$ yaitu dengan menginjeksi STZ $45 \mathrm{mg} / \mathrm{kg}$ BB dan NA $110 \mathrm{mg} / \mathrm{kg} \mathrm{BB}$. Tikus dikatakan mengalami DM apabila kadar glukosa puasa $>250 \mathrm{mg} / \mathrm{dl}^{13,14}$ Berdasarkan hasil yang diperoleh pada kelompok $\mathrm{K}+$ dan $\mathrm{P}$ menunjukkan kadar GDP >250 sehingga memenuhi syarat DM pada tikus. Terjadinya DM tersebut dikarenakan STZ bekerja langsung pada sel $\beta$ pankreas, dengan aksi sitotoksik yang dimediatori oleh reactive oxygen species (ROS). STZ masuk ke sel $\beta$ pankreas melalui glucose transporter (GLUT2) dan menyebabkan menurunnya ekskresi dari GLUT2. ${ }^{15}$ Hal ini mengakibatkan menurunnya sensitifitas reseptor insulin perifer sehingga berdampak pada meningkatnya resistensi insulin dan meningkatkan kadar glukosa darah. ${ }^{16}$ Pemberian NA berfungsi untuk mempetahankan sensitivitas sel $\beta$ pankreas, sehingga tidak menimbulkan toksisitas berlebih yang disebakan oleh STZ. ${ }^{17}$ Mekanisme STZ dalam menginduksi tikus agar mengalami kondisi DM yaitu dengan merusak oksidasi glukosa, menurunkan sintesis dan sekresi insulin, mengganggu transport glukosa dan aktivitas glukokinase di dalam sel $\beta$. Penggunaan STZ dapat mempertahankan kondisi hiperglikemia dalam waktu yang lama. Injeksi NA digunakan untuk mengurangi efek sitotoksik STZ terhadap sel $\beta$ dengan melindungi sel beta pankreas secara parsial. ${ }^{18}$

Berdasarkan Tabel 1, setelah dilakukan uji anova terdapat perbedaan yang signifikan pada kadar GDP tikus antar kelompok, sedangkan uji lanjut duncan menunjukkan perbedaan antara kelompok $\mathrm{K}$ - dan $\mathrm{K}+$, namun pada kelompok $\mathrm{K}+$ dan $\mathrm{P}$ tidak ada perbedaan. Hal tersebut dikarenakan tikus kelompok K- tidak diinjeksi STZ dan NA sehingga kadar GDP masih tergolong normal. Pada kelompok $\mathrm{K}+$ dan $\mathrm{P}$ tidak terdapat perbedaan pada uji lanjut duncan dikarenakan tikus telah mengalami DM.

Berat badan tikus ditimbang setiap tiga hari sekali untuk memantau berat badan subjek. Berdasarkan uji paired t-test terhadap rerata berat badan subjek diketahui bahwa terdapat peningkatan rerata berat badan yang signifikan pada kelompok $\mathrm{K}$ - dan P pada masa aklimatisasi, pengkondisian DM dan intervensi. Pada kelompok $\mathrm{K}+$ terdapat peningkatan rerata berat badan yang signifikan selama aklimatisasi hingga pengkondisian DM tetapi terdapat penurunan yang signifikan selama masa pengkondisian DM hingga intervensi. Berdasarkan hasil uji one way anova tidak terdapat perbedaan signifikan rerata berat badan antar kelompok pada 
masa aklimatisasi dan pengkondisian DM. Penurunan rerata berat badan selama intervensi pada kelompok $\mathrm{K}+$ disebabkan karena kelompok ini mengalami resistensi insulin serta tidak mendapatkan terapi gizi. Resistensi insulin menyebabkan tubuh tidak mampu menyerap glukosa dalam darah secara optimal dan mengganggu proses glikolisis akibatnya memicu terjadinya proses glikogenolisis. ${ }^{18}$ Proses glikogenolisis yang terjadi secara terus menerus dapat menyebabkan terjadinya penurunan berat badan. Tikus kelompok $\mathrm{P}$ (tikus DM) mengalami peningkatan berat badan selama intervensi dikarenakan kelompok ini mendapatkan terapi gizi berupa pakan dengan indeks glikemik rendah, tinggi serat dan antioksidan yaitu tepung sorgum. Pakan ini mampu meningkatkan sensitivitas insulin sehingga tubuh mampu menyerap glukosa dalam darah dan menghentikan proses glikogenolisis. ${ }^{19}$

Selama masa intervensi, terdapat perbedaan signifikan rerata konsumsi pakan antar kelompok K, $\mathrm{K}+$ dan $\mathrm{P}$ berdasarkan hasil uji one way anova. Pada uji post hoc duncan diketahui bahwa perbedaan rerata pakan terdapat pada kelompok $\mathrm{K}+$ dengan kelompok $\mathrm{K}$ - maupun $\mathrm{P}$ tetapi tidak terdapat perbedaan rerata konsumsi pakan pada kelompok Kdengan kelompok P. Rerata konsumsi pakan tertinggi yaitu pada kelompok $\mathrm{K}+$. Hal ini dikarenakan kelompok $\mathrm{K}+$ mengalami resistensi insulin. Keadaan ini akan menyebabkan kinerja leptin dalam mengontrol nafsu makan di hipotalamus dan batang otak menjadi terganggu sehingga tubuh akan terus merasa lapar. ${ }^{20}$

Tabel 2 menunjukkan bahwa kelompok K+ dan $\mathrm{P}$ mengalami hipertensi setelah dikondisikan mengalami DM. Resistensi insulin menyebabkan berkurangnya aktivitas fungsional sel $\beta$ sehingga pada kondisi resistensi insulin atau defisiensi insulin dapat mengganggu proses glikolisis akibat menurunnya kerja enzim glukokinase, fosfofruktokinase, dan piruvat kinase. ${ }^{21,22}$ Efek resistensi insulin akibat diabetes itu sendiri juga dapat menyebabkan hipertensi. ${ }^{23}$ Resistensi insulin membuat tubuh tidak merespon hormon insulin dengan baik, sehingga gagal menyerap gula dalam darah (glukosa) untuk dijadikan energi atau simpanan lemak. Kondisi ini mengakibatkan peningkatan lemak tubuh. Penumpukan lemak dalam tubuh bisa mengganggu kerja sistem saraf, termasuk sinyal yang mengatur tekanan darah. ${ }^{24}$ Selain itu, resistensi insulin memicu ketidakseimbangan kadar garam dan kalium yang menyebabkan peningkatan volume cairan tubuh. Hal ini juga dapat menyebabkan penyempitan arteri, yang lama-lama menaikkan tekanan darah sistolik sehingga terjadi hipertensi. ${ }^{25}$ Tekanan darah tikus dikatakan hipertensi bila tekanan darah sistolik melebihi 120 mmHg. ${ }^{29}$ Sumber lain menyebutkan bahwa hipertensi dicapai setelah tikus mengalami peningkatan tekanan darah $>10 \mathrm{mmHg}$ dari tekanan darah pada kelompok normal. ${ }^{30}$

Kelompok $\mathrm{P}$ mengalami penurunan tekanan darah. Penurunan tekanan darah pada kelompok $\mathrm{P}$ dimungkinkan terjadi karena diberikan pakan yang mengandung tinggi serat dan antioksidan berupa tepung sorgum. Beberapa penelitian telah menunjukkan bahwa serat dapat menurunkan tekanan darah sistolik secara signifikan. ${ }^{26}$ Serat pangan mampu mengurangi kadar kolesterol yang bersirkulasi dalam plasma darah, sebab serat pangan bisa mengikat garam empedu, mencegah penyerapan kolesterol di dalam usus, dan meningkatkan pengeluaran asam empedu lewat feses, sehingga dapat meningkatkan konversi kolesterol plasma menjadi asam empedu. ${ }^{27}$ Serat mempunyai kaitan dengan asam empedu, apabila serat pangan kurang tidak mampu mengurangi kadar kolesterol sehingga tidak mampu mengikat garam empedu, tidak dapat mencegah penyerapan kolesterol dalam usus dan mengakibatkan asam empedu lebih sedikit dikeluarkan feses. Kondisi ini akan mengakibatkan semakin banyak kolesterol dalam darah yang mengakibatkan hipertensi. ${ }^{28}$

Hasil penelitian terhadap aktivitas antioksidan pada sorgum menunjukkan bahwa aktivitas antioksidan yang terdapat di dalam sorgum sebesar $89,32 \%$. Antioksidan yang terdapat dalam sorgum salah satunya adalah antosianin. Antosianin berperan mengurangi resistensi insulin dan meningkatkan sensitivitas insulin sehingga mampu menghambat hormone sensitive lipase (HSL) agar tidak terjadi lipolisis dan peningkatan asam lemak bebas. ${ }^{27}$ Mekanisme antosianin dalam menurunkan tekanan darah yaitu dengan cara menghambat sintesis kolesterol. Antosianin bertindak mengaktifkan adenosin monophosphate-activated protein kinase (AMPK) yang berperan dalam homeostasis energi. AMPK menghalangi HMG-KoA reduktase yang berperan dalam sintesis kolesterol sehingga pengaktifan AMPK akan menurunkan sintesis kolesterol. AMPK juga berperan dalam menurunkan aktivasi Asetil ko-A karboksilase sehingga meningkatkan oksidasi asam lemak dan menurunkan sintesis asam lemak akibatnya terjadi penurunan kadar kolesterol sehingga tekanan darah sistolik menurun. ${ }^{28}$

Tekanan fisiologis tikus normal adalah 100/80 $\mathrm{mmHg}$, dalam penelitian ini tekanan darah sistolik tikus menurun menjadi 113,6 mmHg. Meskipun belum mencapai tekanan darah sistolik tikus normal, namun menurut Thompson, suatu zat uji dikatakan mempunyai efek antihipertensi jika mampu 
menurunkan tekanan darah sistolik $\geq 20 \mathrm{mmHg}$. Jadi, dalam penelitian ini apabila terjadi penurunan tekanan darah sistolik $\geq 20 \mathrm{mmHg}$, maka sudah dapat dikatakan mempunyai efek antihipertensi. ${ }^{31}$

\section{SIMPULAN}

Pemberian tepung sorgum berpengaruh signifikan terhadap tekanan darah sistolik tikus sebelum intervensi dan setelah intervensi. Kelompok $\mathrm{K}$ - dan $\mathrm{K}+$ mengalami peningkatan tekanan darah sistolik, dan pada kelompok $\mathrm{P}$ terjadi penurunan tekanan darah. Penurunan tekanan darah sistolik pada kelompok perlakuan sebesar $89,3 \mathrm{mmHg}$ (43,9\%). Pada kelompok K- dan K+ terjadi peningkatan tekanan darah sistolik sebesar 3,1 $\mathrm{mmHg}(3,4 \%)$ dan $8,1 \mathrm{mmHg}(4,0 \%)$.

Perlu dilakukan penelitian dan pengkajian untuk mengetahui pengaruh makanan olahan tepung sorgum terhadap tekanan darah sistolik penderita diabetes dengan kandungan tinggi serat dan antioksidan.

\section{DAFTAR PUSTAKA}

1. International Diabetes Federation. Global Burden of Diabetes: Diabetic Atlas. 5th ed. Brussel; 2011.

2. International Diabetes Federation. Diabetes in Indonesia. Brussel; 2014.

3. PERKENI (Perkumpulan Endokrinologi Indonesia). Konsensus Pengendalian dan Pencegahan Diabetes Melitus Tipe 2 di Indonesia. PB PERKENI; 2015.

4. Fatimah RN. Diabetes Melitus Tipe 2. J Major. 2015;4(5):93-101.

5. Cho NH, Whiting D, Guariguata L, Montoya PA, Forouhi N, Hambleton I, et al. IDF Diabetes Atlas. 6th ed. Guariguata L, Nolan T, Beagley J, Linnenkamp U, Jacqmain O, editors. International Diabetes Federation; 2013. 1-160 p.

6. Diagnosis and Classification of Diabetes Mellitus, Clinical Practice Recommendations,. USA; 2004.

7. Miller M, Stone NJ, Ballantyne C, Bittner V, Criqui $\mathrm{M}$, Ginsberg $\mathrm{H}$, et al. Triglycerides and Cardiovascular Disease. Circ Am Hear Assoc Journals. 2011;123:2292-333.

8. Yogiantoro M, Meuthia F. JNC VIII- What we learn about, what is new. Naskah lengkap PKB XVI Recent Advances in Cardiovascular Disease SMF Kardiologi dan Kedokteran Vaskular FK Universitas Airlangga-RSUD Dr.Soetomo Surabaya. 2014 Juni. p.87-95.

9. Cooper-DeHoff R.M.,Gang Y, Handberg EM, Bavry AA, Denarjo SJ, Bakris GL, et al. Tight blood pressure control and cardiovascular outcome among hypertensive patients with diabetes and coronary artery disease. JAMA. 2010;304(1):61-8.

10. Fitriani RJ. [Skripsi] Substitusi Tepung Sorgum terhadap Elongasi dan Daya Terima Mi Basah dengan Volume Air yang Proporsional. Universitas Muhammadiyah Surakarta; 2016.

11. Suarni. Pemanfaatan Tepung Sorgum untuk Produk Olahan. Jurnal Penelitian dan Pengembangan Pertanian ; 2004.

12. Stefoska-Needham A, Beck EJ, Johnson SK, Tapsell LC. Sorghum: An Underutilized Cereal Whole Grain with the Potential to Assist in the Prevention of Chronic Disease. Food Rev Int. 2015;31(4):401-37.

13. Ghasemi A, Khalifi S, Jeddy S. Streptozotocinnicotinamide-induced rat model of type 2 diabetes. Acta Physiol Hung [Internet]. 2019;101(4):408-20. Available from: http://www.akademiai.com/doi/abs/10.1556/AP hysiol.101.2014.4.2.

14. Savych A, Marchyshyn S. Investigation of pharmacological activity the new antidiabetic plant gathering in streptozotocin- nicotinamideinduced diabetes in the rats. Pharma Innov J. 2017;6(3):175-7.

15. Rajarajeswari N, Pari L: Antioxidant role of coumarin on streptozotocin- nicotinamideinduced type 2 diabetic rats. J. Biochem. Mol. Toxicol. 2011. 25, 355-361.

16. Darmono, Suhartono T, Tjokorda. Diabetes Mellitus Ditinjau dari Berbagai Aspek Penyakit Dalam. Semarang: Badan Penerbit Universitas Diponegoro; 2007.

17. Pari L, Srinivasan S. Antihyperglycemic effect of diosmin on hepatic key enzymes of carbohydrate metabolism in streptozotocinnicotinamide-induced diabetic rats. Biomed Pharmacother [Internet]. 2019;64(7):477-81. Available from: http://dx.doi.org/10.1016/j.biopha.2010.02.001.

18. Gallagher ML. The Nutrient and Their Metabolism. In: Mahan LK, Escot-Stump S, editors. Krause's Food \& Nutrition Therapy. 12th ed. Canada: Elsevier; 2008. p. 50-9.

19. Nugroho AE. Review: Hewan Percobaan Diabetes Mellitus: Patologi dan Mekanisme Aksi Diabetogenik. Biodiversitas. 2006;7(4):378-82.

20. Zhang M, Lv X-Y, Li J, Xu Z-G, Chen L. The Characterization of High-Fat Diet and Multiple Low-Dose Streptozotocin Induced Type 2 Diabetes Rat Model. Exp Diabetes Res. 2008;1-9.

21. Bender DA, Mayes PA. Glikolisis dan Oksidasi Piruvat. In: Biokimia Harper. 29th ed. Jakarta: 
Penerbit Buku Kedokteran EGC; 2012.

22. Soemantri D, Sukmana M. Hipertensi pada diabetes melitus. Dalam : Hipertensi: Manajemen Komprehensif. Seri buku ilmiah kardiologi SMF Kardiologi dan Kedokteran Vaskular Universitas Airlangga-RSUD Dr Soetomo. p.75-88.

23. James PA, Oparil S, Carter BL, Cushom WC, Dennison-Himmerfarb $\mathrm{C}$, Handler $\mathrm{J}$, et al. Special Communication: 2014 Evidence-Based Guideline for the Management of High Blood Pressure in Adults. Report from the Panel Member Appointed to the Eighth Joint National Committee (JNC 8). JAMA. 2014;311(5):50720.

24. Yogiantoro M, Meuthia F. JNC VIII- What we learn about, what is new. Naskah lengkap PKB XVI Recent Advances in Cardiovascular Disease SMF Kardiologi dan Kedokteran Vaskular FK Universitas Airlangga-RSUD Dr.Soetomo Surabaya. 2014 Juni. p.87-95.

25. UK Prospective Diabetes Study Group. Tight blood pressure control and risk of macrovascular and microvascular complications in type 2 Diabetes: UKPDS 38. BMJ. 1998;317(7160)703- 13.
26. The ACCORD Study Group. Eff ects of intensive blood-pressure control in type 2 diabetes mellitus. N Engl J Med. 2010; 362:1575-85.

27. Mancia G, Forgord R, Narkiewicz K, Redan J, Zanchetti A, Böhm M, et al. 2013 ESH/ ESC Guidelines for the Management of Arterial Hypertension. European Heart Journal. 2013;34,2159- 219.

28. Part 2: Recommendations for hypertension treament. In Canadian Hypertension Education Program (CHEP) Recommendations [internet] 2019. [Cited 2019 Spet 15] Available from http:// www.hypertension.ca/en/chep.

29. Guyton AC, Hall JE. 2006. Buku Ajar Fisiologi. Edisi ke-11. Jakarta: EGC.

30. Ciptaningsih E. 2012. Uji Aktivitas Antioksidan dan Karakteristik Fitokimia pada Kopi Luwak Arabika dan Pengaruhnya terhadap Tekanan Darah Tikus Normal dan Tikus Hipertensi. Program Studi Magister Ilmu Kefarmasian. Fakultas MIPA. Universitas Indonesia.

31. Fidrianny I, Padmawinata K, Soetarno S, Yulinah E. 2003. Efek Antihipertensi dan Hipotensi Beberapa Fraksi dari Ekstrak Etanol Umbi Lapis Kucai (Allium schoenoprasum L., Lliliaceae). Jurnal Mat Si Volume (8): 147-150 